\title{
Risaæxli í hóstarkirtli - sjúkratilfelli
}

Elín Maríusdóttir', Karl Erlingur Oddason¹, Sigfús Nikulásson², Tómas Guð̋bjartsson ${ }^{1,3}$

ÁGRIP

Æxxli i hóstarkirtli eru yfirleitt góðkynja og staðsett i framanverðu miðmæti. Hér er lýst afar sjaldgæfu risaæxli i hægra brjóstholi sem reyndist vaxið út frá hóstarkirtli. ÆExlið sem mældist 15 × 8 cm reyndist hóstarkirtilsæxli (thymoma) af gerð AB og tókst að fjarlægja pað með skurðaðgerð. Tveimur árum eftir aðgerð er sjúklingur einkennalaus og án merkja um endurkomu sjúkdóms.
Fyrirspurnir: Tómas Guőbjartsson tomasgud@landspitali.is

Greinin barst 3. desember 2013, sampykkt til birtingar

30. apríl 2014.

\section{Inngangur}

Hóstarkirtilsæxli eru misleitur hópur æxla með fjölbreytileg einkenni og horfur. Pau eru sjaldgæf en engu að síður algengustu æxli upprunnin í miðmæti. ${ }^{1}$ Í íslenskri rannsókn var aldursstaðlað nýgengi 0,28/100.000 íbúa og reyndist svipað fyrir bæði kyn. ${ }^{2}$ Meðalstærð hóstarkirtilsæxla í peirri rannsókn var $6,5 \mathrm{~cm}$ og var stærsta æxlið 9,5 cm. ${ }^{2}$ Risaæxlum í hóstarkirtli hefur verið lýst í erlendum rannsóknum ${ }^{3}$ og hér er slíku tilfelli lýst í fyrsta skipti á Íslandi.

\section{Sjúkratilfelli}

Áður hraust 75 ára kona leitaði til heimilislæknis eftir að hafa verið með verki ofarlega í kvið og undir hægra rifjabarði í nokkra mánuði. Verkirnir höfðu ekki tengsl við máltíðir, hún hafði aldrei reykt og aldrei fengið hjarta- og æðasjúkdóma. Hún kvartaði ekki um mæði, brjóstverki eða önnur einkenni frá lungum, né heldur megrun eða nætursvita. Hún tók einungis blóðfitulækkandi lyf að staðaldri. Við skoðun voru veikari öndunarhljóð yfir hægra lunga en engin aukahljóð heyrðust yfir lungum. Kviður var mjúkur og engar fyrirferðir við preifingu. Blóðrannsóknir sýndu blóðrauða og hvít blóðkorn innan eðlilegra marka líkt og C-reactive protein (CRP) og lifrarpróf.

Gerð var ómskoðun af lifur og gallvegum sem sýndi eðlilega lifur og gallblöðru án gallsteina. Hins vegar sást við ómunina skuggi í efra brjóstholi. Pví var gerð tölvusneiðmynd af brjóstholi sem sýndi $13 \times 12 \mathrm{~cm}$ péttingu í neðri hluta hægra brjósthols sem lá pétt að hægra lungnaporti og miðmæti (mynd 1).

Grunur vaknaði um sarkmein en ástunga sýndi ekki illkynja frumur og benti pví frekar til góðkynja æxlis. Ákveðið var að taka konuna til aðgerðar og var æxlið fjarlægt í gegnum fremri brjóstholsskurð hægra megin. Í aðgerðinni sást að æxlið, sem var vel afmarkað

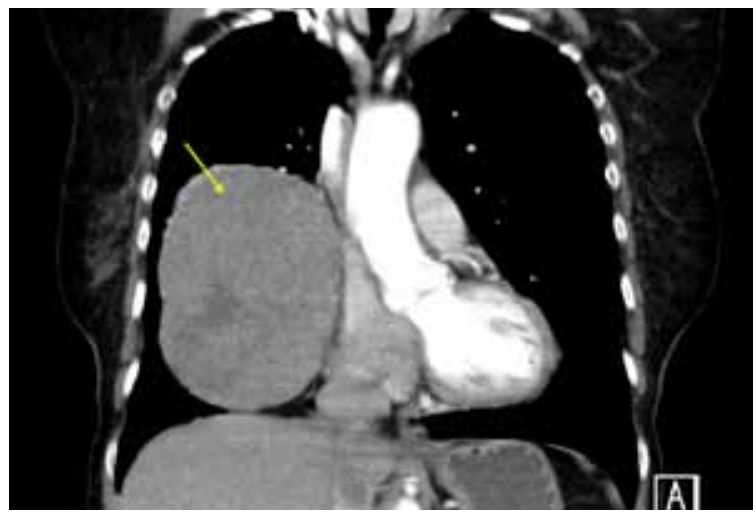

Mynd 1. Tölvusneiðmynd af brjóstholi sem sýnir æxlið íhægra brjóstholi (ör).

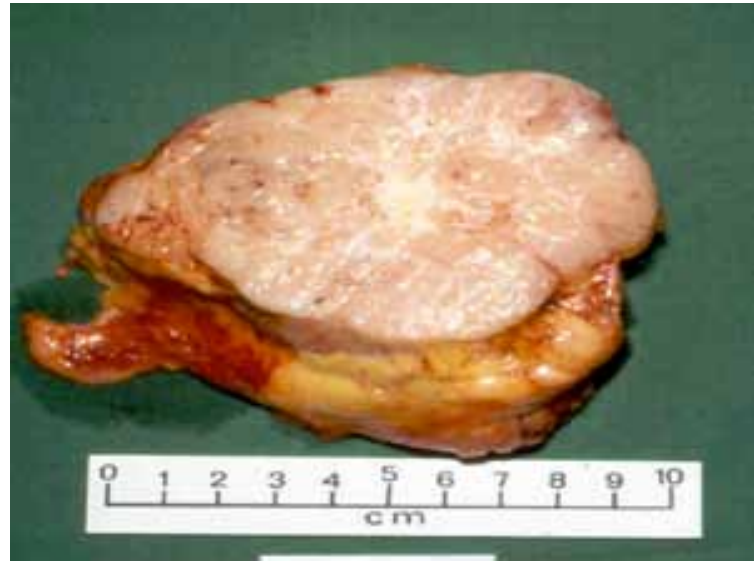

Mynd 2. Ljósmynd af cexlinu sem var hart viðkomu. Stilkurinn sem teygði sig inn að miðmati er neðst til vinstri á myndinni.

frá lunganu og brjóstveggnum, fyllti alveg út í neðri priðjung hægra brjósthols. Æxlið reyndist vaxa út úr fremra miðmæti, nánar tiltekið hóstarkirtlinum, með 8 cm löngum stilk. Hóstarkirtillinn með æxlinu var fjarlægður í heild sinni (mynd 2) og sýndi vefjagreining að æxlið var hóstarkirtilsæxli af gerð $\mathrm{AB}, 15$ × 13 × $8 \mathrm{~cm}$ 


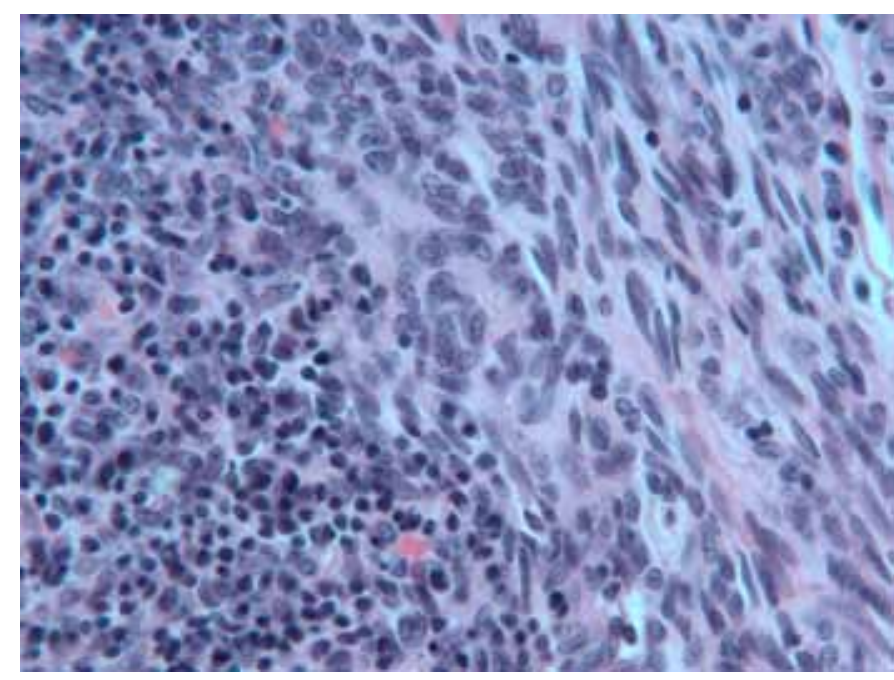

Mynd 3. Smásjármynd af cexlinu sem reyndist hóstarkirtilscexli af gerð $A B(H \& E$ litun). Sjá má blöndu af sporöskjulaga pekjufrumum sem einkenna gerð A og hringlaga pekjufrumum ásamt eitilfrumum sem einkenna gerð B.

stórt (mynd 3). Bati var góður eftir aðgerð og tveimur árum síðar er hún við góða heilsu og engin merki um endurkomu.

\section{Umræða}

Hér er lýst risaæxli í brjóstholi sem reyndist góðkynja hóstarkirtilsæxli, nánar tiltekið af gerð AB. Aðeins nokkrum slíkum risaæxlum hefur verið lýst áður. ${ }^{3}$ Í flestum tilvikum greinast risaæxli vegna einkenna frá lungum, fremur en vegna kviðverkja, eins og var raunin í pessu tilfelli. Athyglisvert er að konan hafði ekki haft nein einkenni frá öndunarfærum prátt fyrir að æxlið prýsti á stóran hluta hægra lunga.

Hóstarkirtilsæxli greinast yfirleitt um miðjan aldur en lýst hefur verið tilfellum bæði í öldruðum og börnum. Algengustu einkenni eru hósti, mæði eða brjóstverkur en sjaldgæfari einkenni eru hæsi, kyngingarörðugleikar og einkenni vöðvaslensfárs (myasthenia gravis). ${ }^{4}$ Um priðjungur sjúklinga eru einkennalausir og greinast fyrir tilviljun við myndrannsóknir á brjóstholi sem gerðar eru vegna annarra sjúkdóma eða einkenna. ${ }^{5}$

Helstu mismunagreiningar risaæxla í brjóstholi eru lungnakrabbamein, sarkmein, SFTP-æxli (solitary fibrous tumor of the pleura), fósturkímsæxli (germ cell tumor), eitilkrabbamein og paraganglioma. ${ }^{6}$ Konan hafði aldrei reykt og pví minni líkur á lungnakrabbameini. Engu að síður er vert að hafa í huga að allt að $10 \%$ lungnakrabbameina greinast í sjúklingum sem aldrei hafa reykt. ${ }^{7}$ Sýnataka með ástungu benti hvorki til sarkmeins né annarra illkynja æxla og æxlið var vaxið út frá miðmæti en ekki fleiðru á brjóstvegg eins og er dæmigert fyrir SFTP-æxli. ${ }^{8}$

Gróflega er hóstarkirtilsæxlum skipt í góðkynja og illkynja æxli eftir útliti pekjufrumna sem mynda æxlið. Góðkynja æxli, pað eru æxli í flokki A, B og AB vaxa hægt, hafa góðar horfur og meinvarpast sjaldan. ${ }^{9}$ Hegðun peirra getur pó verið óutreiknanleg og hætta er á staðbundinni endurkomu, jafnvel áratugum eftir brottnám. Einnig geta hóstarkirtilsæxli orðið mjög stór og prýst á eða vaxið inn í mikilvæg líffæri í miðmæti, eins og talin var hætta á í pessu tilfelli. $^{10}$

Illkynja æxli í hóstarkirtli (thymic carcinoma) eru mun sjaldgæfari en pau góðkynja, en í nýlegri íslenskri rannsókn voru pau 20\% hóstarkirtilsæxla. ${ }^{2}$ Pau hafa gjörólíka hegðun og horfur, meinvarpast snemma og dánartíðni af peirra völdum er há .11

Aðalmeðferð hóstarkirtilsæxla er skurðaðgerð par sem hóstarkirtillinn er fjarlægður ásamt aðliggjandi fitu, oftast í gegnum bringubeinsskurð. ${ }^{12}$ Í pessu tilfelli fyllti æxlið stóran hluta hægri brjósthols og var pví ákveðið að fjarlægja pað í gegnum hægri brjóstholsskurð. Æxlið var mjög stórt en reyndist pó ekki vaxið í aðliggjandi líffæri sem auðveldaði brottnám pess.

Við stigun hóstarkirtilsæxla er stuðst við svokallað Masaokakerfi. Í pví er lagt mat á íferð æxlisins í hýði kirtilsins, aðliggjandi fitu og nálæg líffæri, en einnig hvort fjarmeinvörp séu til staðar. ${ }^{13}$ Masaoka-stig við greiningu hefur mest að segja um horfur pessara sjúklinga en einnig hvort tekst að fjarlægja allt æxlið með hreinum skurðbrúnum. ${ }^{14}$ Á Masaoka-stigum 1 og 2 er í flestum tilvikum aðeins beitt skurðaðgerð. Vaxi æxlið hins vegar ífarandi og/eða fjarmeinvörp eru til staðar (Masaoka stig 3 og 4) er oft beitt krabbameinslyfjum og/eða geislum, en síður skurðaðgerð. ${ }^{15}$ Árangur meðferðar hjá sjúklingum með óskurðtæk illkynja æxli (á stigi 4) er pó ekki eins vel rannsakaður og fyrir góðkynja æxlin par sem horfur eru mjög góðar. 2,14

Pakkir fær Maríanna Garðarsdóttir fyrir aðstoð við frágang röntgenmynda.

\section{Heimildir}

1. Venuta F, Anile M, Diso D, Vitolo D, Rendina EA, De Giacomo T, et al. Thymoma and thymic carcinoma. Eur J Cardiothorac Surg 2012; 37: 13-25.

2. Mariusdottir E, Nikulasson S, Bjornsson J, Gudbjartsson $\mathrm{T}$. Thymic epithelial tumours in Iceland: incidence and histopathology, a population-based study. APMIS 2010; 118: 927-33.

3. Limmer S, Merz H, Kujath P. Giant thymoma in the anterior-inferior mediastinum. Interact Cardiovasc Thorac Surg 2009; 10: 451-3.

4. Moore KH, McKenzie PR, Kennedy CW, McCaughan BC. Thymoma: trends over time. Ann Thorac Surg 2001; 72: 203-7.

5. Muller-Hermelink HK, Marx A. Thymoma. Curr Opin Oncol 2000; 12: 426-33.

6. Wright $\mathrm{CD}$, Mathisen DJ. Mediastinal tumors: diagnosis and treatment. World J Surg 2001; 25: 204-9.
7. Thun MJ, Hannan LM, Adams-Campbell LL, Boffetta P, Buring JE, Feskanich D, et al. Lung cancer occurrence in never-smokers: an analysis of 13 cohorts and 22 cancer registry studies. PLoS Med 2008; 5: e185.

8. Guo W, Xiao HL, Jiang YG, Wang RW, Zhao YP, Ma $\mathrm{Z}$, et al. Retrospective analysis for thirty-nine patients with solitary fibrous tumor of pleura and review of the literature. World J Surg Oncol 2011; 9: 134.

9. Chen G, Marx A, Wen-Hu C, Yong J, Puppe B, Stroebel P, et al. New WHO histologic classification predicts prognosis of thymic epithelial tumors: a clinicopathologic study of 200 thymoma cases from China. Cancer 2002; 95: 420-9.

10.Johnson SB, Eng TY, Giaccone G, Thomas CR, Jr Thymoma: update for the new millennium. Oncologist 2001; 6: 239-46.

11. Detterbeck FC. Clinical value of the WHO classification system of thymoma. Ann Thorac Surg 2006; 81: 2328-34.
12. Fang W, Chen W, Chen G, Jiang Y. Surgical management of thymic epithelial tumors: a retrospective review of 204 cases. Ann Thorac Surg 2005; 80: 2002-7.

13. Lardinois $D$, Rechsteiner $R$, Lang RH, Gugger M, Betticher D, von Briel C, et al. Prognostic relevance of Masaoka and Muller-Hermelink classification in patients with thymic tumors. Ann Thorac Surg 2000; 69: 1550-5.

14. Venuta F, Anile M, Diso D, Vitolo D, Rendina EA, De Giacomo T, et al. Thymoma and thymic carcinoma. Eur J Cardiothorac Surg 2012; 37: 13-25.

15. Kondo K, Monden Y. Therapy for thymic epithelial tumors: a clinical study of 1,320 patients from Japan. Ann Thorac Surg 2003; 76: 878-84; discussion 84-5. 


\section{ENGLISH SUMMARY}

\section{Giant thymoma - case report}

Elin Mariusdottir ${ }^{1}$, Karl Erlingur Oddason', Sigfus Nikulasson², Tomas Gudbjartsson ${ }^{1,3}$

Thymomas are usually benign tumors and are most often found in the anterior mediastinum. We report a rare case of a giant tumor in the right hemithorax that originated in the thymus. The tumor was $15 \times 8 \mathrm{~cm}$ and histology revealed a type $A B$ thymoma. The tumor was removed and the patient is doing well and is without symptoms two years after the operation.

Key words: Thymoma, abdominal pain, giant tumor, mediastinum

Correspondence: Tómas Gư̋bjartsson, tomasgud@landspitali.is

Departments of ${ }^{1}$ Cardiothoracic Surgery and ${ }^{2}$ Pathology, Landspitali University Hospital, ${ }^{3}$ Faculty of Medicine, University of Iceland. a 